ISSN: 2162-3104 Print/ ISSN: 2166-3750 Online

Volume 8, Issue 1 (2018), pp. 473-487

(C) Journal of International Students

http://jistudents.org/

doi: $10.5281 /$ zenodo. 1134345

\title{
Learning Styles: A Comparison Between Indian And German Business Students
}

\author{
Tushar Bhatnagar \\ Vinita Sinha \\ SCMHRD Pune, India
}

\begin{abstract}
Every individual is characterized by a learning style which an individual develops over a course of time. The learning style may be shaped by different cultural environment. This study aims to find and compare the learning style of Indian and German business students by examining the learning styles of 81 students from India and Germany. The study uses Learning Style Questionnaire introduced by Honey and Mumford. The findings suggest that there is significant difference in the learning style of Indian and German students. Indian students are found to be observed to reflect, analyze and theorize whereas German students are more oriented towards practical application of theory followed by reflection and analysis. Findings have also been thoroughly discussed in terms of the geographical constructs.
\end{abstract}

Keywords: learning styles, German, Indian, business, students

Because of globalization, knowing learning styles of future business managers from different cultural backgrounds has become important for a number of reasons. First, it is important to understand how business managers learn in a business environment. This will help to design proper training and development programs for their learning. It is also important to the education industry as there is more cross-cultural student exchange of business students than few years ago. Pedagogical research has acknowledged that learners often come from varied backgrounds and sociocultural settings, with corresponding differing learning styles (Bollinger, 2003). The misalignment of instructor's style of teaching and learner's 
method of learning has often been cited as a potential learning barrier (Vita, 2001). Research has shown that a match between learning environments and learner's learning styles can enhance learner's performance, motivation and efficiency (Oxford \& Ehrman, 1992; Sampson \& Karagiannidis, 2004). There have been business exchanges between India and Germany as many German companies like Bosch, Mercedes, and BMW have manufacturing plants in India. The increased number of student exchange have also enabled future managers to know each other. More interaction between Indian and German companies will help to design training programs for employees. Due to these positive changes, it becomes increasingly important to understand learning styles of business students of India and Germany.

\section{Research Questions}

1. Which are the dominant learning styles of Indian business students?

2. Which are the dominant learning styles of German business student?

3. Is there a difference in learning styles of Indian and German business students?

\section{Learning Styles}

Every person has his or her own individual way of gathering and processing information, which means ways of learning and solving problems in day-to-day situations. These personal cognitive abilities, acquired in the course of a long socialization process are called "learning styles" (Reynolds, 1997; Barmeyer, 2004).

The learning style concept has been recognized at least since the mid-1970s (Griffiths, 2012). It was found that students working in learning situations that matched with their learning styles and preferences had higher achievement (Hunter, 1978; Fung et al., 1993; Kolb, 2014).

\section{Learning Style Inventory and Learning Style Questionnaire}

Few researchers have studied learning styles of people across countries by employing various learning style methods such as Kolb's Learning Style Inventory (LSI) and Honey's and Mumford's Learning Style Questionnaire (LSQ) which has evolved from Kolb's LSI. Kolb (1976, 1984) describes a four-stage cycle of learning divided across two dimensions. The four stages are divided into Abstract Conceptualization (AC), Reflective Observation (RO), Concrete Experience (CE), and Active 
Experimentation (AE). Two axes AC-CE and AE-RO, signify two basic dimensions of learning. Four different groups are formed when plotting student learning styles across the two axes: assimilators, consisting of abstract conceptualization and reflective observation; divergers, consisting of reflective observation and concrete experience; accommodators, consisting of concrete experience and active experimentation and Convergers, consisting of active experimentation and abstract conceptualization (Allinson, 1988). Divergers reflect on specific experiences from a number of different perspectives; Assimilators develop a theoretical framework on the basis of that reflection; Convergers test the theory in practice; and Accommodators use the result of that testing as a basis for new learning.

While Honey and Mumford accepted LSI, they felt there was a need to identify a learning style that was more meaningful to the managerial population. Therefore, Honey and Mumford (1986) developed the LSQ to measure four basic learning styles which they define as follows.

\section{Activists}

The Activists' philosophy is: 'I will try anything once'. Activists involve themselves fully and without bias in new experiences. They enjoy the here and now and are happy to be dominated by immediate experiences. They are open-minded, not skeptical, and this tends to make them enthusiastic about anything new.

\section{Reflectors}

The Reflectors' philosophy is to be cautious. They are thoughtful people who like to consider all possible angles and implications before making a move. They collect data, both first hand and from others, and prefer to think about it thoroughly before coming to any conclusion.

\section{Theorists}

The Theorists' philosophy prizes rationality and logic. If it's logical it's good. Theorists adapt and integrate observations into complex but logically sound theories. They think problems through in a vertical, step by step, logical way. They assimilate disparate facts into coherent theories. They tend to be perfectionists who won't rest easy until things are tidy and fit into a rational scheme. They like to analyze and synthesize. They are 
keen on basic assumptions, principles, theories, models, and systems thinking.

\section{Pragmatists}

The Pragmatists' philosophy is: There is always a better way If it works it's good. Pragmatists are keen on trying out ideas, theories, and techniques to see if they work in practice. They positively search out new ideas and take the first opportunity to experiment with applications. They are the sort of people who return from management courses brimming with new ideas that they want to try out in practice. They like to get on with things and act quickly and confidently on ideas that attract them.

The extent to which an individual is attracted towards, or repelled by, particular kinds of learning activity can be established through LSQ. Constructed largely through questions about managerial behavior, the LSQ establishes levels of attraction or repulsion through the scoring of answers. LSQ has been accepted as a preferable mode of measurement learning styles (Allinson and Hayes, 1988)

\section{LITERATURE REVIEW}

Romanelli (2009) have argued that knowledge of learning styles can be of use to both educators and students. Teachers with awareness of learning styles can shape learning materials so that they relate to learning styles exhibited by students. Students who know their own preferences are empowered to use different techniques to enhance learning which consequently, may enhance overall educational experience.

Many educators are faced with the problem of how to handle the different ways in which students from different cultures approach learning. Manikutty et al. (2007) acknowledge that learning styles may vary from culture to culture. Sulimma (2009), outlines how differing epistemological beliefs may influence an individual's learning behavior, and thus guide selfregulatory cognition and engagement including the use of cognitive learning strategies (Cools et al., 2009). It has been found difficult to isolate individual factors. Zhu et al. (2010) explore that prior experience in addition to culture plays part in learning of students taking part in e-learning environment. This increased interest in the potential external factors such as culture, education, socialization and social environment (Cools et al., 2009). Culture may mean adoption of customs and behaviors which is the attribute of countries. Many authors have based their studies on learning styles of 
particular countries (Barmeyer, 2004; Charlesworth, 2008; Jaju et al., 2002); therefore, the authors tried to measure the impact of culture on learning styles. Comparative studies have been done for France, Germany, and Quebec (Barmeyer, 2004); Indonesia, China and France (Charlesworth, 2008); U.S., India and Korea (Jaju et al., 2002). Barmeyer (2004) discovered that business students of France, Germany and Quebec show little difference in reflective observation; however, Germany was found to incline towards assimilator and Converger behavior which shows that German business students are good in inductive reasoning and theorizing (assimilator) and are also strong in practical hands-on application of theories (Converger). Charlesworth (2008) discovered that Indonesian, Chinese and French students show difference in learning style based on cultural background. It was found that Indonesian students tend to prefer tried and tested practical ideas, whereas Chinese and French students seek new and different challenges. Jaju et al. (2002) found that undergraduate business students from India, Korea and U.S. show significant difference in learning styles. Indian students were found to be Convergers, U.S. students were found to be divergers; whereas, Koreans were found to be assimilators. Holtbrügge and Mohr (2009) found that learning style preferences differ across countries and that these preferences are affected by a number of cultural values. Literature on learning styles has also been based on gender, and various disciplines such as engineering, statistics, tourism, and nursing. Chan and Mak (2010) found differences in learning styles based on gender. According to their study, female students of the tourism institute in Macao were found to show strong preference towards Reflector behavior compared to male students. Dziedzic, Oliveira, Janissek, and Dziedzic (2013) measured the efficacy of questionnaire related to learning style such as Kolb, and HoneyAlonso and Felder-Soloman and found Felder-Soloman to be more reliable than others by taking a sample of engineering students. Yousef (2015) measured learning style preferences of undergraduate statistics students in a United Arab Emirates (UAE) university using Felder and Soloman's ILS and found no statistically significant difference along the four dimensions.

However, some researchers are skeptical about the validity on the use of learning styles. Both Eaves (2011) and Sulimma (2009) highlight the fact that much of the research into learning styles reflects the Western cultural context given that the major learning styles models and measures have originated from Europe and North America (Cools, et al., 2009). More research is required among different cultures to reach meaningful decision.

\section{Impact of Culture}


It has been argued by Pratt (1992) through a body of work that learning styles may vary based on culture. Other studies in the area try to find out how learning styles or approaches vary across culture (De Vita, 2001; Paul \& Arcodia, 2002). Using Felder and Soloman's Index of Learning Styles, De Vita (2003) found out that greater variations in learning styles exist in culturally heterogeneous class. Paul and Arcodia determined that students of Confucian heritage culture exhibited different learning style when studying in the University of Queensland, Australia.

The definition of culture according to Hofstede (1991): "The collective programming of the mind that distinguishes the members of one group or category of people from another" (p. 5).

For the sake of study that is based on learning style of students, two of the dimensions presented by Hofstede will be explained. Hofstede argued that for teacher student relationship, these two dimensions play the most important role.

Individualism-Collectivism: The relationship between individual and the group. In a collectivistic society, group interest over-ride individual interests. In an individualistic society, individual interests take precedence over group interests. India is part of a collectivistic society while Germany is part of an individualistic society.

Power distance: Social inequality, including relationship with the authority. In low Power Distance societies, the weight is towards equality. India scores 77 on Power distance while Germany scores 35 and hence India has more high-power distance.

\section{RESEARCH METHOD}

\section{Sample}

For this study, 41 Master of Business Administration (MBA) students in Human Resources, Marketing, Operations, Finance course students from India and 40 Master program students of Business in Human Resources, Strategy, and Finance from Germany participated. Culture impacts learning styles marginally according to Joy \& Kolb (2009). Therefore, only those students were selected who were citizens of that country and were studying in the country of their citizenship since the past 6 months to make sure their learning style does not change significantly by exposure to a different culture. All 41 students from India were Indian students and all 40 students from Germany were German students and 
satisfied the above criteria. The universities which were selected were well renowned universities in their countries. All these universities have at least one exchange program in another country. Symbiosis University and Berlin School of Economics and Law (BSEL) have a mutual exchange program for their students.

Table 1. Respondent information.

\begin{tabular}{|c|c|c|}
\hline Demographics & India & Germany \\
\hline Age range & $20-30$ & $21-32$ \\
\hline Mean age & 25.07 & 25.1 \\
\hline Male & 32 & 12 \\
\hline Female & 9 & 28 \\
\hline Undergraduate & 11 & 3 \\
\hline Postgraduate & 30 & 37 \\
\hline Sample Size & 41 & 40 \\
\hline University & $\begin{array}{l}\text { Symbiosis University } \\
\text { (39), IIT Kanpur (1), } \\
\text { XIMB Bhubaneshwar (1) }\end{array}$ & $\begin{array}{l}\text { Berlin School of } \\
\text { Economics and Law } \\
\text { (Hochschule fuer } \\
\text { Wirtschaft und Recht } \\
\text { Berlin) }\end{array}$ \\
\hline
\end{tabular}

\section{Data Collection}

To gather the required data, online and offline mechanisms were used. All the students who participated from India answered the questionnaire online, and seven German students answered online. The response rate for Indian students was $60 \%$. For German students, the response rate was $90 \%$. For the rest of the answers, the survey was conducted in classes of Human Resources, Strategy, and Finance by taking 25 min for the surveys. 34 students completed the questionnaire.

\section{Measure}

To measure learning styles, LSQ (Honey and Mumford, 1986) has been used over Learning Style Inventory (LSI). Research conducted by Allinson and Hayes (1988) suggested LSQ may be preferable over LSI for a number of reasons. First, the LSQ seems capable of measuring something. Whereas LSI has no clear factor structure, the LSQ was able to distinguish 
similar cognitive dimensions in two independent samples. Also, it may be more reliable. Temporal stability coefficients for the LSQ appear to be superior to those reported for the LSI. Finally, it has a better face validity. While a number of the LSI items do not inspire confidence as indicators of learning style, the behavioral statements contained in the LSQ at least look as though they measure what they are supposed to be measuring.

LSQ was designed to measure the relative strength of the four basic learning styles defined as Activists, Reflectors, Theorists, and Pragmatists. It consists of 80 questions and has 20 items for each learning style. The items describe a behavior that the student may demonstrate, while some of them probe a preference or a belief. Students are required to indicate whether the statements apply to them by agreeing or disagreeing. Agree has a score one attached while Disagree has zero score. Therefore, a student can score a maximum of 20 for each learning style.

\section{FINDINGS AND ANALYSIS}

It emerges from the survey that Indian students showed a high inclination towards Reflector style of learning. 58.54\% of Indian participants showed a preference towards Reflector style. While German students had a mixed preference. $30 \%$ were inclined towards Pragmatist style of learning while nearly $27 \%$ showed preference towards Reflector style of learning.

rable 2. Learning style preference of Indian students.

\begin{tabular}{lcc}
\hline Learning style & Count & Percentage \\
\hline Activist & 3 & 7.32 \\
Activist-Pragmatist & 1 & 2.44 \\
Activist-Reflector-Pragmatist & 1 & 2.44 \\
Pragmatist & 2 & 4.88 \\
Reflector & 24 & 58.52 \\
Reflector-Pragmatist & 4 & 9.76 \\
Reflector-Theorist & 1 & 2.44 \\
Reflector-Theorist-Pragmatist & 1 & 2.44 \\
Theorist & 4 & 9.76 \\
\hline
\end{tabular}


Table 3. Learning style preference of German students.

\begin{tabular}{lcc}
\hline Result & Count & Percentage \\
\hline Activist & 4 & 10.0 \\
Activist-Reflector-Pragmatist & 1 & 2.5 \\
Pragmatist & 12 & 30.0 \\
Reflector & 11 & 27.5 \\
Reflector-Pragmatist & 2 & 5.0 \\
Reflector-Theorist & 3 & 7.5 \\
Theorist & 5 & 12.5 \\
Theorist-Pragmatist & 2 & 5.0 \\
\hline
\end{tabular}

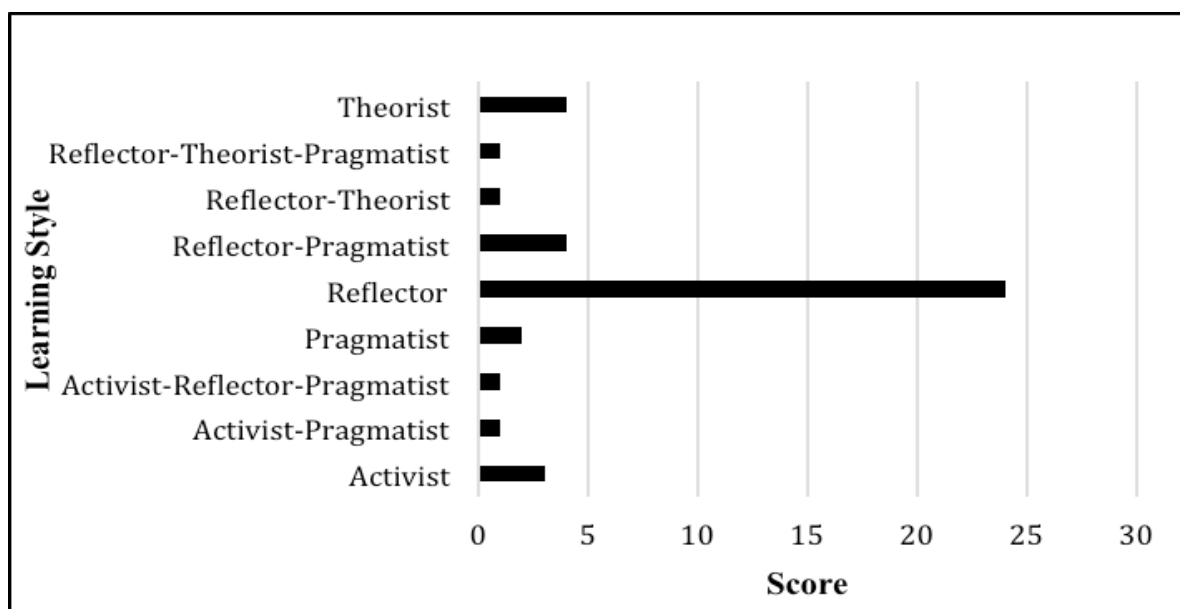

Figure 1. Preferred Learning style of Indian business students

The prominent learning style of Indian business students:

- Reflector (58.54\%)

The two most prominent learning styles of German business students:

- Pragmatist (30\%)

- Reflector $(27.5 \%)$ 
Figure 2. Preferred learning style of German students.

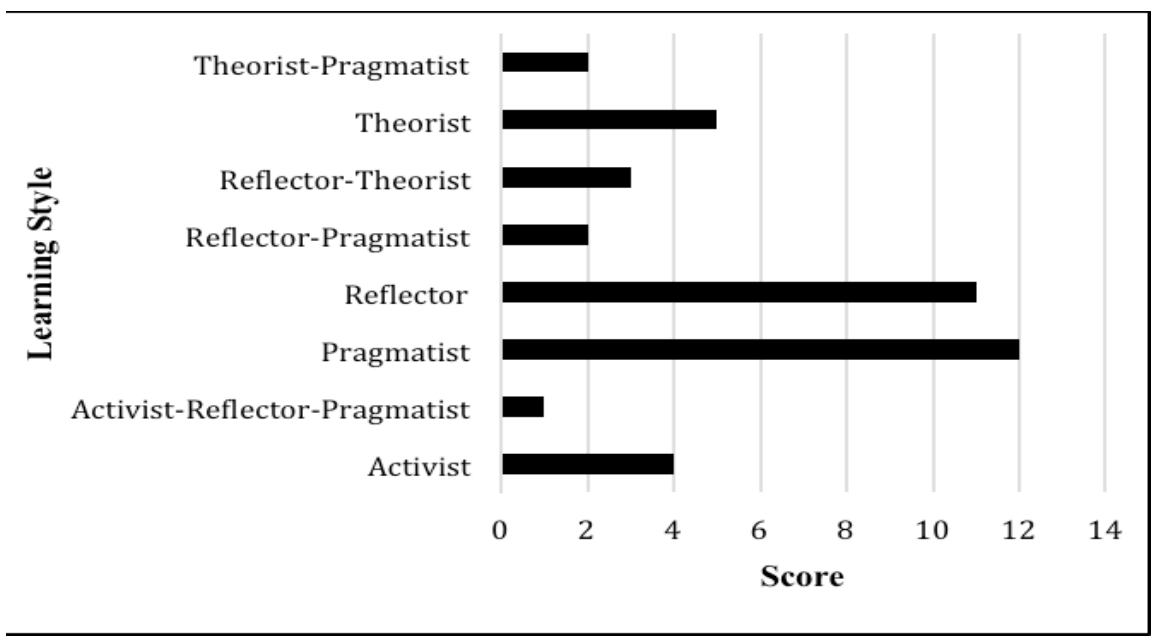

\section{DISCUSSION}

The two prominent studies conducted in the past used Kolb's Learning style inventory (LSI) and hence it is imperative to understand meaning of LSQ in relation to LSI. There is arguably strong similarity between the Honey and Mumford styles and the corresponding Kolb learning styles: Activist = Accommodating; Reflector = Diverging; Theorist = Assimilating; Pragmatist $=$ Converging (Dziedzic, et al., 2013). The previous study conducted on Indian students using LSI by Jaju, et al. (2002) found that Indian business undergraduate students conformed towards Converger style. This means that Indian students exhibited Pragmatist trait. However, the results found in this study were contradictory to the study conducted by Jaju, et al. The results indicate that business students in India show a very strong preference towards Reflector style followed by Theorist style. The above difference may be attributed to the fact the sample collected in this study had very few undergraduate business students ( 2 out of 41 ). Teacher-student relationship, in terms of power distance can be termed as high-power distance, not in terms of power but there is a distance between students and teachers. Therefore, it can be asserted that Indian students, in general, reflect before they take a decision. A decision can be as simple as raising a question in the class. It may also be pointed out that Indians' working style is more people oriented. According to Sirje Virkus (2009), who studied leadership dimensions based on the results of GLOBE study, found that effective 
leadership behavior of Southern Asia countries of India, Iran, Indonesia, Malaysia, Philippines, and Thailand is more sensitive towards people's need and concerned with status and face-saving. Hence, the predominant collectivistic nature of Indians can explain why Indians are people oriented. Emphasis is also given among Indian students to learn through conceptual theoretical knowledge (Theorist). This can be gauged from the fact many Indian management aspirants sit for a management entrance exam every year to enter prestigious management institutions in the country.

The results of the study by Barmeyer (2004) found German business students in the Assimilating quadrant (42.9\%) followed by Converging quadrant (32.7\%). This suggests German business students are Theorists followed by Pragmatists in their learning style. Whereas German business students in this study show a strong preference towards Pragmatist and Reflector style of learning. Research orientation of Germany can be one of the reasons why German students have been seen to exhibit practical approach (Pragmatist). Plus, teacher -student relationship in terms of power distance has lesser power distance. Hence, it can be argued that German students take the hands-on, practical approach by raising questions when necessary to find solutions. Germans are part of an individualistic society. This can explain why German students give more emphasis to structures than people. Attention to detail is regarded as one of the values of Germans (Zimmermann, 2015). Showing more emphasis to structures and detail are preferences of a Pragmatist style of learning (Ismail, n.d.).

In both the cases, it is important to note that the small sample size of the present study might have affected the outcome of the results compared to previous studies and therefore, must be seen with caution.

\section{LIMITATIONS}

Only three universities were selected in India and one university was selected in Germany for survey. Though, students come from all over the country to participate in these universities, still bigger sample size would help to strengthen validity of the results.

The results were restricted by few dual and triple learning styles emerging throughout the survey and lack of literature on dual and triple learning styles restricted the interpretation of these styles. Nielson (2012) reported changes in learning styles of Business Administrations and Psychology students over 1, 2, and 3 years of study. It is recommended that periodical assessment of learning styles is taken for better design of instructional materials. 
Individual cultural dimension scores of participants should have been taken. This would have helped to analyze the impact that cultural dimensions make on their learning styles. The reason for difference in learning styles has been discussed but lack of cultural dimension values has made it difficult to support the claims. This can be a crucial piece of information for future studies.

\section{IMPLICATIONS OF THE STUDY}

The results of the LSQ in this study can help practitioners to understand the kind of learning material that can be prepared for the audience in these countries to learn better and become more productive. Preferred learning styles should be taken into consideration when developing curricula which are accessed by business students from India as well as Germany. Based on the results of future managers, organizations can design management training and development programs catering to their needs. Secondly, the study can help to provide insight into why some students may find it difficult to grasp information when they move to different learning environment. This can help in doing preparatory work these students which could be helpful.

\section{CONCLUSION}

The LSQ findings show that learning styles of Indian and German business students differ. However, the contribution of culture on learning styles can be one of many reasons. This also suggests that Indian and German managers may exhibit different style of learning. When the students and managers from these two cultures work together in teams, different learning styles will meet. Therefore, training is suggested to adapt to each other's style. On the other hand, meeting of diverse cultures is also a precious source of cultural synergy (Barmeyer, 2004) and therefore beneficial for the individuals and organizations to grow.

\section{REFERENCES}

Allinson, C., \& Hayes, J. (1988). The learning styles questionnaire: An alternative to Kolb's inventory? Journal of Management Studies, 25(3). doi: 10.1111/ j.1467-6486.1988.tb00036.x

Barmeyer, C. I. (2004). Learning styles and their impact on cross-cultural training: An international comparison in France, Germany and Quebec. 
International Journal of Intercultural Relations, 28(6), 577-594. doi: 10.1016/j.ijintrel.2005.01.011

Berings, M., Poell, R., Simons, P., \& Van Veldhoven, M. (2007). The development and validation of the on-the-job learning styles questionnaire for the nursing profession. Journal of Advanced Nursing, 58(5). doi: 10.1111/ j.1365-2648.2007.04252.x

Bollinger, L. C. (2003). The need for diversity in higher education. Academic Medicine, 78(5), 431-436.

Brusilovsky, P., Karagiannidis, C., \& Sampson, D. (2004). Layered evaluation of adaptive learning systems. International Journal of Continuing Engineering Education and Life Long Learning, 14(4-5), 402-421.

Carmona, C., Castillo, G., \& Millán, E. (2007). Discovering student preferences in e-learning. In Proceedings from International Workshop on Applying Data Mining in e-learning (pp. 33-42). Retrieved from https://www.researchgate.net/profile/Eva_Millan/publication/228356097_

Discovering_Student_Preferences_in_ELearning/links/0fcfd50bc794cab513000000.pdf

Chan, C. S., \& Mak, W. (2010). The use of learning styles questionnaire in Macao. Industrial and Commercial Training, 42(1), 41-46. doi: 10.1108/ 00197851011013706

Charlesworth, M.Z. (2008). Learning styles across cultures: suggestions for educators. Education + Training, 50(2), 115-127. doi: 10.1108/ 00400910810862100

Cools, E., Evans, C., \& Redmond, A.J. (2009). Using styles for more effective learning in multicultural and e-learning environments. Multicultural Education \& Technology Journal, 3(1), 5-16. doi: 10.1108/ 17504970910951110

Dziedzic, M., de Oliveira, F. B., Janissek, P. R., \& Dziedzic, R. M. (2013). Comparing learning styles questionnaires. In 2013 IEEE Frontiers in Education Conference (pp. 973-978). IEEE. doi: 10.1109/FIE.2013. 6684972

Eaves, M. (2011). The relevance of learning styles for international pedagogy in higher education. Teachers and Teaching: Theory and Practice, 17(6), 677-691. doi: 10.1080/13540602.2011.625143

Fung, Y., Ho, A., \& Kwan, K. (1993). Reliability and validity of the Learning Styles Questionnaire. British Journal of Educational Technology, 24(1). doi: 10.1111/j.1467-8535.1993.tb00637.x

Hofstede, G. (1991). Cultures and organizations. Software of the mind. London: McGraw Hill.

Goulding, J., \& Syed-Khuzzan, S. (2014). A study on the validity of a four-variant diagnostic learning styles questionnaire. Education + Training, 56(2/3), 141-164. doi: 10.1108/ET-11-2012-0109

Griffiths, C. (2012). Learning styles: Traversing the quagmire. In Psychology for language learning (pp. 151-168). Palgrave Macmillan. 
Hatami, S. (2013). Learning styles. ELT Journal, 67(4), 488-490. doi: $10.1093 / \mathrm{elt} / \mathrm{ccs} 083$

Holtbrügge, D., \& Mohr, A. T. (2009). Learning style preferences of management students: A cross-cultural perspective. Working Paper. University of Erlangen-Nuremberg, University of Bradford. Retrieved from http://www. econbiz. de/archiv1/2010/102592_learning_style_preferences. pdf.

Hunter, W (1978) Noncognitive factors and student success in college. Community College Frontiers, 7(2), 44-47.

Ismail, M. A. A. Honey Mumford's Learning Style Questionnaire (LSQ).

Jaju, A., Kwak, H., \& Zinkhan, G. M. (2002). Learning styles of undergraduate business students: A cross-cultural comparison between the US, India, and Korea. Marketing Education Review, 12(2), 49-60. doi: 10.1080/ 10528008.2002.11488787

Joy, S., \& Kolb, D. A. (2009). Are there cultural differences in learning style?. International Journal of Intercultural Relations, 33(1), 69-68. doi: 10.1016/j.ijintrel.2008.11.002

Kolb, D. A. (2014). Experiential learning: Experience as the source of learning and development. FT press.

Kolb, D. A. (1984). Experiential learning: Experience as the source of learning and development. Prentice-Hall. Englewood Cliffs, NJ

Manikutty, S., Anuradha, N. S., \& Hansen, K. (2007). Does culture influence learning styles in higher education? International Journal of Learning and Change, 2(1), 70-87. doi: 10.1504/IJLC.2007.014896

McChlery, S., \&Visser, S. (2009). A comparative analysis of the learning styles of accounting students in the United Kingdom and South Africa. Research in Post-Compulsory Education, 14(3), 299-315. doi: 10.1080/ 13596740903139404

McKee, T. E., Mock, T. J., \& Ruud, T. F. (1992). A comparison of Norwegian and United States accounting students' learning style preferences. Accounting Education, 1(4), 321-341. doi: 10.1080/09639289200000049

Minkov, M., \& Hofstede, G. (2011). The evolution of Hofstede's doctrine. Cross Cultural Management: An International Journal, 18(1), 10-20, doi: $10.1108 / 13527601111104269$

Mumford, A. (1995). Putting learning styles to work: an integrated approach. Industrial and Commercial Training, 27(8), 28-35. doi: 10.1108/ 00197859510097072

Oxford, R. L., \& Ehrman, M. (1992). Second language research on individual differences. Annual Review of Applied Linguistics, 13, 188-205. doi: $10.1017 / \mathrm{S} 0267190500002464$

Reynolds, M. (1997). Learning styles: A critique. Management Llearning, 28(2), 115-133. doi: 10.1177/1350507697282002

Romanelli, F., Bird, E., \& Ryan, M. (2009). Learning styles: A review of theory, application, and best practices. American Journal of Pharmaceutical Education, 73(1), 9. 
Sulimma, M. (2009). Relations between epistemological beliefs and culture classifications. Multicultural Education \& Technology Journal, 3(1), 7489. doi: $10.1108 / 17504970910951165$

Swailes, S., \& Senior, B. (1999). The dimensionality of Honey and Mumford's Learning Styles Questionnaire. International Journal of Selection and Assessment, 7(1). doi: 10.1111/1468-2389.00099

Vita, G. D. (2001). Learning styles, culture and inclusive instruction in the multicultural classroom: A business and management perspective. Innovations in Education and Teaching International, 38(2), 165-174. doi: $10.1080 / 14703290110035437$

Yousef, D. (2016). Learning styles preferences of statistics students. Quality Assurance in Education, 24(2), 227-243. doi: 10.1108/QAE-01-2014-0004

Zhu, C., Valcke, M., \& Schellens, T. (2010). A cross-cultural study of teacher perspectives on teacher roles and adoption of online collaborative learning in higher education. European Journal of Teacher Education, 33(2), 147165. doi: 10.1080/02619761003631849

Zimmermann, K. A. (2015). German Culture: Facts, Customs and Traditions. (2015, January 23). German culture: Facts, customs and traditions. Retrieved from http://www.livescience.com/44007-german-culture.html

TUSHAR BHATNAGAR, pursued Master of Business Administration (MBA), at Symbiosis Centre for Management \& Human Resource Development (SCMHRD) Pune (2015-17). Email: tushar_bhatnagar@ scmhrd.edu

VINITA SINHA, PHD, is an Associate Professor at SCMHRD Pune. Email: vinita_sinha@scmhrd.edu 